\title{
GLOBALIZATION AND POVERTY IN ROŞIA MONTANĂ
}

\author{
Lucia Ispas-Pascaru ${ }^{1}$ \\ Mihai Pascaru ${ }^{2}$
}

\begin{abstract}
Globalization is a concept that, for the past decades, carried on dreadful fears, as well as great expectations. Defined as a process of global intercommunication and interconnection of economical, political, cultural forces and actors, globalization leads to a global network that enables transnational spread of information, technologies, capital, commodities, structures, cultures and people, representing a major change in the social structure of society. In this context we witness new fears and also, new hopes considering the state of communities, democracies, freedom and identity. Romania entered a transition process from a closed society to a hub in the global network with the dawn of communist era, even though the forces of globalization per se empowered the struggle against the communist regime. Roşia Montană, a mining locality in Apuseni Montains, in the context of the debates over the mining project proposed by Roşia Montană Gold Corporation (RMGC), represents a natural laboratory of observation for social scientists, gathering the main concerns of modernization: the interaction between global economic forces and local cultures, the empowerment of local community and civil society, the tension between economic interest and cultural and environmental preservation. In this context, the study emphasizes the analysis of people's life standard and expectations in Roşia Montană, in the context of globalization. Admitting that globalization is a multidimensional concept, ambiguous and ambivalent in its consequences, we analyze its possible risks and benefits on the quality of life in Roşia Montană.
\end{abstract}

Key words: globalization, objective poverty, subjective poverty, corporate social responsibility, sustainable development.

JEL code: EOO.

Globalization is a multidimensional concept that emphasizes the changes in modern society, transforming it from a society of "national boundaries" to a global network of interdependencies that links together national economies, cultures and policies. The appearance of global entrepreneurs, the development of the global market, the flow of foreign capital, the spread of technology (dimensions of economical globalization), intertwines with the appearance of global social issues, and, as implied, global organisms, economical, political or non governmental, called to solve them, the spread of cultural patterns and the construction of new cultures at the intersection of global and local forces, as well as, as feared, the disappearance of some traditional cultures and forms of social organization. The literature focuses on analyzing and describing the nature, the causes and consequences of this process. Kellner (2002), in his article Theorizing Globalization, summarizes the main perspectives on the concept, pleading against "one-sided optics", for a perspective that integrates the contradictory forces and dimensions of the process seen as a "highly complex, contradictory, and thus ambiguous of institutions and social relations, as well as, involving flows of goods, services, ideologies, technologies, cultural forms and people" (Kellner, 2002:285). Economic determinism is seen as reductionist, focusing on the rise of global entrepreneurs, the transnational flow of capital and commodities, processes that lead to cultural,

\footnotetext{
${ }^{1} 1$ Decembrie 1918 University, Alba Iulia, Romania.

21 Decembrie 1918 University, Alba Iulia, Romania.
} 
social and political changes. On one side, from this perspective, the consequences are seen as positive per se, global capitalization leading to global welfare and pressures for democratization and free market. On the other hand, authors draw attention to the downside of globalization: one of the major consequences that sociologists fear of is the loss of local cultures and communities; the flow of goods, commodities and information leads to a unified market, a homogenous mass culture that dissolves local cultural forms. Also, globalization brings new forms of marginalization and poverty, for the groups and societies at the periphery of the global network. Professor Yusufu Bala Usman draws attention to the ideological and political load of this concept, considering that it could be used as an instrument "to impose their goods, their services, their capital investments and their hole life style, over us, so they continue to obtain profit from our resources, production and consumption and keep us undermined from a political, economical and cultural point of view" (Usman, in Pascaru, 2007). Usman considers that, defining globalization as a process of connections and interdependency relations intensification, up to the drastic limitation of national boundaries that encloses information, finance, goods and services flows, leaves you with two options: "either you subject to its force, either you are carried away and abandoned, impoverished and exiled to the periphery of human development, development determined by the same global forces" (Usman, in Pascaru, 2007:22) An important observation drawn by Kellner is the fact that economical, cultural and political changes are intertwined, creating circles of interdependencies and, therefore, globalization must be analyzed also as a bottom-up process, through which marginalized groups or cultures are empowered to resist globalization, to use "its institutions and instruments to further democratization and social justice" (Kellner, 2002:293). The tension between global and local forces gives rise to new forms of association and cultures, dislocating and sometimes dissolving traditional communities and cultural forms, the pressure for uniformity has also a reverse consequence- the need for a stronger process of identification and differentiation, as a coping mechanism. Ulrike Schuerkens (2002) considers globalization as an interaction between unifying forces that spread all around the world and resistance forces that struggle for maintaining the local life worlds and peculiar cultures. The interaction between these processes, leads to new forms of adaptation to modernity and western culture, crystallizing in new forms of hybrids between western modernity and eastern traditions, different forms of resistance to uniformity and different forms of dislocation of traditional cultures (Schuerkens, 2003). The global pressure for uniformity empowers the resistance struggle, interacting with local forces to create new hybrid forms. This interference between local and global social forces is explain by Schuerkens, as a need to reaffirm and reinvent local cultures and identities in order to maintain stability and continuity, facing the threat of unstable, rapid global changes. Glocalization refers to the mutual interference and empowerment of global and local forces that give rise to new forms of glocal cultures (217). The concept also brings to attention new forms of resistance to uniformity and hegemony of mass culture, the fact that in the context of global connectivity and communication people move out of the "little boxes" toward an individualized network of relations that are not based on local proximity, but on social and axiological vicinity. In the context, new forms of association and differentiation appears, "translocal cultures" represent a mixture of local traditions, dislocated into global relations, yet, not at all ubiquitous or hegemonic, but even marginal (Wellman 2002, 1983; for the theory of network society see also Castells, 2000).

Schuerkens fears that the resistance mechanisms of local cultures is only a short term effect and that on long term, the global forces could lead to enormous changes in the local world lives. Therefore, he emphasizes the political dimension of glocalization, concluding that "the relation between global forces and local life-worlds cannot be explained only by structural transformation, but also by force", so that, "political engagement can emphasize either the long term perspective of globalization, either the national or regional local life-world diversity (Schuerkens, 2003, in Pascaru, 2007:20).

Romania, as other ex-communist countries, enters the global network from a state 
dominated economy, relatively closed, under the pressure of global forces toward a greater democratization and free market. The collapse of state companies leaves most areas with no means of production, entrepreneurial culture or capital, but with a great unemployed work force. Mining areas and other specialized industrial areas were declared disadvantaged areas, with a great population living in extreme poverty. The only escape seen, in this context, was the foreign capital infusion.

In this context, in 1997, Eurogold (Denumirea iniţială a companiei Roşia Montana Goldcorporation) proposes a project of mining exploitation in Roşia Montană, a mining locality in Apuseni Mountains. At that point in Roşia Montană, Minvest S.A. Deva, the National Company of Cuprum, Gold and Iron, could not sustain a project of that magnitude. Relying on concepts as free market, sustainable development, cultural and environmental preservation, and diverse actors launched into public debates, unprecedented in the public sphere of a new democracy. The benefits promised by RMGC emphasized the economical dimension, an investment for at least 25 years estimated in 2002 at 700 millions USD, could bring benefits: 1) local public administration budget growth; 2) employment; 3) opportunities for economical activities for those unemployed by RMGC; 4) investment in infrastructure; 5) regional development. The main arguments of the opponents were the concerns regarding sustainable development, environmental and cultural preservation raising questions about the future of the local community after the exploitation is done. Even though RMGC project have had a component of environmental restoration after the exploitation was done, the fact that the exploitation extends over almost 20.000 ha was considered an impact to big to be restored. Another concerns expressed by the civil society, politicians, journalist, and local community was regarding cultural and historical preservation. Roşia Montană is a locality first attested almost 2000 years ago, that was until 1977 in UNESCO Universal Patrimony, an archeological sit threatened to be destroyed.

At the interference of these global and local forces the project proposed by RMGC evolved toward a better understanding of local community needs and a corporate social responsibility oriented management. As a response new expectations and issues arise. This unprecedented dialogue brings Roşia Montană to attention, as a natural laboratory of observation for social scientists.

In this context, we are interested in analyzing two major aspects of life quality that arise at the interference of global forces with the local community: 1) what is the objective life standard of people in Roşia Montană and 2) how are the objective life conditions (life standard and social conditions, fears and opportunities) internalized and perceived by individuals 3 ) which are the main vulnerability factors in this context. The research, developed under the aegis of "Muntii Apuseni" Center of Research and Socioeconomic Development, was designed as an exhaustive research, following a methodology similar to a census. The study includes 831 responses from households (from 963, identified by field operators) because the refusals could not be avoided completely and information about 32 households could not be obtained to direct questioning.

\section{Employment and work force qualification}

As other rural areas Roşia Montană faced a drastic and continuous collapse of the economical activity in the last decades. In the past two years, in the context of global crisis we can see evidence of economical continuing decline and growth of unemployment, Roşia Montană loosing over $29 \%$ of jobs. Our research finds that the unemployment rate reaches over $20 \%$ in 2009. From this only $8 \%$ are unemployment aid beneficiary. The category of those employed is small, only $16 \%$ are employed in public or private institutions, and overwhelmed by $55 \%$, retired and $22 \%$ unemployed (see table 1 ).

Analyzing the vulnerability factors to unemployment we find that the main explanation resides in the poor qualification. The most vulnerable category is that of primary and secondary education graduates. We can observe that the vulnerability is considerably lower for college 
graduates.

Another vulnerability factor is ethnicity, we can observe that more then $62 \%$ of Rroma population in the locality is unemployed (only $14 \%$ of which is unemployment aid beneficiary) and has primary or secondary school studies only.

Table no. 1.

\section{Occupational status}

\begin{tabular}{||c|c||}
\hline Occupational status & \% \\
\hline Unemployed (unregistered) & 14 \\
\hline Retired & 5 \\
\hline Unemployed (registered) & 8 \\
\hline $\begin{array}{l}\text { Employed } \\
\text { Housewife or worker in their own } \\
\text { household }\end{array}$ & 7 \\
\hline Total & 100 \\
\hline
\end{tabular}

Source: author's contribution

\section{Life standard. Income and expenditures}

Unemployment has direct consequences on life standard and quality of life, from an objective and a subjective point of view. Analyzing household incomes, we observe that the category that concentrates most of the people is 300-1200 lei, and the distribution decreases slowly and equally towards the extremes. The highest frequency is registered in the category 300-600 lei, $20 \%$, followed by $600-900$ lei, $14 \%$ and $900-1200$ lei, with $12 \%$. At the extremes we find $12 \%$ living with 100 or less, and $4 \%$ living with 2400 or more.

Concerning household expenditures, we find a relative symmetry with the incomes, the highest frequency $22 \%$, being registered on the 300-600 lei interval, followed by 0-300 lei, with $16 \%$ and 600-900 lei, with 16\%. As noted in Ispas-Pascaru and Moldovan (2010), we found a very low saving capacity/household especially for the young Rroma, households with the age of household head between 16 and 25 (51\% of this category being forced to borrow money in the precedent month), with poor education and unemployed, and for both Rroma and Romanian households, with the age of the household head between 26 and 45 years (35\% of this category being forced to borrow money in the precedent month). Taking a closer look to the main expenditure categories we find that for the population investigated, a proportion of $51 \%$ of expenditures are for food (see Ispas-Pascaru and Moldovan, 2010). A high proportion of food expenditures reveals a low quality of life, focused on survival were the opportunities for other aspects of development are almost inexistent.

\section{Subjective poverty. Changing expectations and self-labeling as poor}

Subjective poverty refers to the way in which objective life conditions are internalized at the interference with subjective perceptions and expectations. In the context of globalization new issues arise, global forces that dislocate traditional communities and rising welfare pressure toward a more individualized society and greater democratization, massive urbanization and international migration reveals new, accentuated forms of exclusion and social inequity, so that the economic dimension of quality of life remains insufficient in explaining social exclusion and marginalization. Subjective poverty takes into consideration the feelings of poverty experienced by individuals, considering that determinant for life strategies, for the way social actors perceive social realm, for the life satisfaction, are not objective life conditions, but the subjective evaluation, the subjective representations over the equity of the social system and over their own position in the system, the way individuals evaluate their own life standard based on expectations and need built in the social 
context.

In Roşia Montană the appearance of a new global actor shapes people`s expectations and perception over the social system. The perspectives drawn by RMGC project and also the presence of a new category with a higher social and financial status, change people's expectation over the decent life standard. Even so, this change in people's expectations is not specific only to this community and can be observed in other rural communities, even in relatively closed networks (low stock of bridging social capital and high stock of bonding social capital) the implicit contact with commodities and services on the open market, with cultures and life styles through mass media, have a great impact on people`s expectations, changing the reference points for comparison. Global society, even though we can still find forms of association resemble to traditional communities, shapes expectations and representations at the intersection of local and global trends. An evaluation study conducted in Roşia Montană, in 2002, by Planning Alliance, observes the household dependency of financial incomes, situation that seams unexpected for the authors, phenomenon explained partially by the fact that globalization leads to changes in patterns of consumption and needs even in the most traditional communities.

In Pascaru and Moldovan (2010) we analyze subjective poverty using two indicators subjective life standard and self-labeling as poor. Subjective life standard refers to the subjective evaluation of incomes compared with necessities. In the studied community we found that for most of the people, $41 \%$, the incomes are enough only for the necessary minimum, $32 \%$ considering that their incomes are not enough not even for a decent living, 18\% evaluate their incomes as enough for a decent living, but they can not afford more expensive commodities (it would be interesting to go further and investigate what expensive goods mean for them), only $3 \%$ evaluate their incomes as enough to buy more expensive goods, but with effort and a similar proportion find their incomes as sufficient for everything they need without big efforts (see table 2).

Table no. 2.

\section{Subjective life standard}

\begin{tabular}{|l|c|}
\hline $\begin{array}{l}\text { Total incomes subjectively evaluated compared to } \\
\text { necessities }\end{array}$ & $\%$ \\
\hline \hline $\begin{array}{l}\text { We manage to have everything we need with low } \\
\text { efforts }\end{array}$ & 3 \\
\hline $\begin{array}{l}\text { We manage to buy more expensive things but with } \\
\text { effort }\end{array}$ & 3 \\
\hline \hline $\begin{array}{l}\text { We have enough for decent living, but we can`t } \\
\text { afford expensive things }\end{array}$ & 18 \\
\hline \hline We have enough only for minimum necessities & 41 \\
\hline $\begin{array}{l}\text { Are [have?]not enough not even for minimum } \\
\text { necessities }\end{array}$ & 32 \\
\hline \hline No response & 3 \\
\hline TOTAL & 100 \\
\hline
\end{tabular}

Source: author's contribution

Going a little further, we wonder on the main vulnerability factors and we observe those considering that incomes are not enough for minimal necessities are first of all those unemployed, $34 \%$, with low qualification, 36, with household incomes/month below 600 lei. An important finding consistent with the conclusion of the objective indicators is that a major vulnerability factor is ethnicity; from the total Romanian population only 23 evaluate their incomes as not enough for survival, compared to $78 \%$ in the case of Rroma population. The best evaluation of incomes we find between employees and retired. Most of the retired worked in mining so that the pension is 
relatively big and also a safer and stable source of income. The risks and incertitude of social environment affect in greater proportion those at an active age (between 25 and 55) especially if their work qualification is poor.

\section{Self-labeling as poor}

Self labeling as poor is an indicator that requires respondents to indicate how they see them self [s]on a ten points scale of poverty, 1 meaning very poor and 10 meaning very rich. In the studied community we find that the overwhelming majority consider themselves as being poor or very poor (63\% place them selves 1 and 4 and over 90\% choose between 1-5). Voicu (2006) considers that the median points on the scale 4-5 represent for the people a psychological limit of poverty, ,the individuals that place themselves on this position are those who define themselves on a median position concerning economical compared to whole society, as a reference group" (Voicu, 2006:100)

In the article Life Quality in Roşia Montană. Self-labeling as Poor and Subjective Life Standard, we find that, if the vulnerability for feeling very poor ( 1 on the scale) is stronger for Rroma households (74\% of those feeling very poor is represented by Rroma population) unemployed heads of households, with poor work qualification and low education, mainly young with ages between 26-45 years, the chances of feeling poor or moderately poor (2-5) are the same for Rroma and Romanian population, for the employed and the unemployed (especially for those receiving an unemployment aid), with low or medium education. The vulnerability is lower for the retired (as explained above) and for employees with high education.

\section{Concluding remarks}

We find, in Roşia Montană, not only a poor community, but a community that feels even poorer. The negative evaluation over their own material status and position in the social system launches new work hypothesis, being important to investigate in further research what is the significance for this population of being poor or decent living, what are their expectations and which are the reference groups of comparison.

Roşia Montană, as other areas, confronts its self with a negative inheritance of dysfunctional exploitation and with continuous poverty. Globalization has its downsides, but it can't be considered inherent good or bad. In the context of public empowerment, globalization gives the instruments for a sustainable development for the community. Sustainable development is a concept brought up at the intersection of global forces and local communities and refers to the progress of a society, community that doesn 't enter in conflict with the future of that community, is the form of economic growth that satisfies the needs of a society on short and on long term.

\section{References}

1. Castells M., 2002. Materials for an exploratory theory of the network society, in British Journal of Sociology Vol. 51, No. 1 (January/March 2000) pp. 5-24, London School of Economics.

2. Ispas-Pascaru L., Moldovan S., 2010. Calitatea vieţii la Roşia Montană. Autoetichetarea ca sărac şi standardul subiectiv de viaţă, in Studii şi cercetări în domeniul ştiinţelor socioumane, Cluj-Napoca, Editura Argonaut, p. 250-259.

3. Kellner D., 2002. Theorizing Globalization, in Sociological Theory, Vol. 20, No. 3. November 2002, pp. 285-305, SAGE Publication.

4. Pascaru M., 2007. Habitatul risipit de globalizare. Edit. Argonaut. Cluj-Napoca.

5. Schuerkens U., 2003. Social Transformation Between Global forces and Local LifeWorlds: Introduction, în Current Sociology, May/July 2003, Vol. 51, pp. 195-208, SAGE Publications. 
6. Schuerkens U., 2003. The Sociological and anthropological Study of Globalization and Localization, in Current Sociology, May/July 2003, Vol. 51, pp. 209-222, SAGE Publications.

7. Voicu B., 2006. Cât de săraci sunt românii: abordări subiective şi consensuale, Calitatea Vieţii, nr. 1-2, p. 93-116.

8. Wellman B., 1983. Network analysis: Some Basic Principles, in Sociological Theory, vol. 1, p.155-200.

9. Wellman B., 2002. Little Boxes, Glocalization, and Networked Individualism, in Digital Cities II: Computational and Sociological Approaches, edited by Makoto Tanabe, Peter van den Besselaar and Toru Ishida, Springer, Berlin, p. 10-25. 